\title{
ZISWAF Digital Payment as An Effort to Reach Millennials
}

\section{Fuad Hasyim}

Universitas Islam Negeri (UIN) Raden Mas Said Surakarta, Indonesia email: fuad.hasyim@iain-surakarta.ac.id

\section{Muhammad Al-Farido Awwal}

Universitas Islam Negeri (UIN) Sunan Kalijaga Yogyakarta, Indonesia email:mafaliaal@gmail.com

\section{Nur Hidayah Al Amin}

Universitas Islam Negeri (UIN) Raden Mas Said Surakarta, Indonesia email: zollo212212@gmail.com

\begin{abstract}
ZISWAF is an Islamic-led fundraising instrument aimed at wealth distribution. The existence of technological developments allows the adaptation of payments with all its acceleration. This study aims to determine the digital payment strategy to maximize ZISWAF's revenue potential in Indonesia. This study uses the TAM, and TPB modification approaches. The methodology used is structural equation modeling (SEM) with a partial least square (PLS) approach. The sample used is the Y generation as a representation of the millennial generation. The results showed that all the variables forming the TAM theory (perceived usefulness, perceived ease of use, attitude) and all the variables creating the TPB theory (subjective norms and perceived behavior control) significantly affect the Intention (INT) of individuals pay for online ZISWAF (sig. $<0.05, \alpha=5 \%$ ). Furthermore, attitude is a mediating variable in a partial/ quasi modification model that links perceived usefulness (PU), perceived ease of use (PEoU) to Intention (INT) (VAF=49.87\%).
\end{abstract}

Keywords: TAM; TPB; ZISWAF; SEM; PLS

\begin{abstract}
Abstrak: ZISWAF adalah instrumen pengumpulan dana yang dipelopori Islam dengan tujuan untuk distribusi kekayaan. Adanya perkembangan teknologi memungkinkan adaptasi pembayaran dengan segala akselerasinya. Penelitian ini bertujuan untuk mengetahui strategi pembayaran digital untuk memaksimumkan potensi pendapatan ZISWAF di Indonesia. Penelitian ini menggunakan pendekatan modfikasi TAM dan TPB. Metodologi yang digunakan adalah structural equation modeling (SEM) dengan pendekatan partial least square (PLS). Sampel yang digunakan merupakan generasi Y sebagai representasi generasi milenial. Hasil menunjukkan seluruh variabel pembentuk teori TAM yakni perceived usefulness (PU), perceived ease of use (PEoU) dan attitude (ATT) dan seluruh variabel pembentuk teori TPB yakni subjective norms (SN) dan perceived behavior control (PBC) berpengaruh
\end{abstract}

Economica: Jurnal Ekonomi Islam - Volume 11, Nomor 2 (2020) 
Fuad Hasyim, Muhammad Al-Farido Awwal, and Nur Hidayah Al Amin

terhadap intention (INT) individu dalam membayar ZISWAF secara online (sig. $<0.05, \alpha=5 \%$ ). Attitude (ATT) merupakan variabel pemediasi dalam model modifikasi yang bersifat partial/ quasy yang menghubungkan perceived usefulness (PU), perceived ease of use (PEoU) terhadap intention (INT) $(\mathrm{VAF}=49.87 \%)$.

Kata Kunci: TAM; TPB; ZISWAF; SEM; PLS 


\section{Introduction}

Zakat collection in Indonesia over the past five years has grown at an annual rate of more than 24 percent per year. Well above the yearly average of national economic growth for the same period, which is slightly above 5 percent? That means that the awareness of Muslims in Indonesia to fulfill the virtues of their zakat according to sharia and statutory regulations has increased very well. As a result, in 2018, the collection of ZIS, nationally in the calculation process, is expected to exceed the target of IDR 8 trillion. However, this amount is only $3.5 \%$ of the estimated potential of the national zakat in 2018, amounting to $1.57 \%$ of GDP or around Rp 230 trillion (Baznas 2019).

There is a considerable gap between the potential of zakat with the amount of zakat collected and distributed. The gap raises many questions, given a large number of Zakat Management Organizations (Organisasi Pengelola Zakat/ OPZ) in Indonesia and the amount of government attention on zakat. The level of public trust in the accountability of OPZ (BAZ and LAZ) is the first issue. The level of trust is also inseparable from the community's view of the accuracy of ZISWAF funds distribution from muzakki distributed to mustahik, whether they are right on target and optimal in efforts to improve their welfare through innovative and productive programs.

One criticism that was later evaluated in collecting zakat was by making innovations in the payment of zakat. Therefore, zakat, infaq, sadaqah, and Waqf (ZISWAF) are promoted through digital services. ZISWAF collection services through FinTech integration began to be announced in 2016. BAZNAS became a pioneer in the development of digital alms platforms. Since digital alms was rolled out in 2016, by mid-2019 digital zakat transactions have reached 10 percent or Rp 28 Billion of the total national zakat (Republika 2019).

The initial inspiration for digital alms began with FinTech with the concept of Crowdfunding like kitabisa.com. Therefore, since BAZNAS 
introduced digital alms to the public, the innovation was followed by other zakat institutions (LAZ) such as LazisMu, LazisNU through NU-Care, Dompet Dhuafa, Rumah Zakat, and others. Then the innovation continues on mobile banking that provides digital zakat services originally initiated by BSM through an ATM. The marketplace also improvises with similar services, as Tokopedia, Shopee, and BukaLapak. Even start-ups such as Grab and Gojek provide digital zakat services through e-money in the form of OVO and GoPay (N. S. Simamora 2019). LinkAja and Paytren, as FinTech based financial services, also provide digital alms services.

Based on data from Bank Indonesia (BI), the amount of electronic money at the end of December 2018 reached 167.21 million transactions. This figure increased $85.78 \%$ compared to the previous year. Electronic money has grown above $45 \%$ in the past five years, with 310.72 million volume transactions. If seen in nominal terms, it has reached IDR 47.2 trillion. This growth is the highest when compared to five years back. While the development of e-wallets such as GoPay shows a positive change. Based on the Gojek release dated February 1, 2019, throughout 2018, gross transaction value (GTV) or user transactions on Gojek reached the US $\$ 9$ billion or equivalent to Rp 125 trillion. A transaction using GoPay reached US \$ 6.3 billion, equivalent to Rp87 trillion. This figure is almost equal to $69.6 \%$ of the total Gojek transaction (Franedya 2019).

Based on this background, it is interesting to study the implementation of online ZISWAF, with digital payments through the mosque and commercial environment, given the enormous potential for online transactions in Indonesia. Nowadays, people's lives cannot be separated from technology, especially the people's lifestyles, which prefer practical and easy things. Almost every millennial population in their productive age has e-wallet service applications such as Go-pay, OVO, Dana, T-Cash, and others for transaction purposes. Thus, researchers want to explore the potential associated with alms payments at mosques that are synergized with e-wallet 
services considering that most millennial people of productive age often save money in the form of electronic balances rather than cash. In addition, millennials have the behavior to carry a smartphone more often than a manual wallet.

This research also originated from the researchers' anxiety when they were about to give alms, but no cash was held, while only cash balances were available on e-wallet services. This study uses the TAM approach and TPB approach to explain technology acceptance in ZISWAF payment in Indonesia. Several previous research results found that the digitization of transactions is still limited by the constraints of public acceptance, where Indonesia is still classified as having weak digital literacy. In addition, the coverage of cellular signal access is also an obstacle in the use of digital transaction-based applications (Utami et al. 2020). In previous research, the majority focused more on acceptance proxied through the theory of acceptance model (TAM) (Lai 2017; Karmanto, Mahri, and Nurasyiah 2021; Purwanto, Sulthon, and Wafirah 2021; Wiharjo and Hendratmi 2020). However, it has not touched the personal realm in forming attitudes or habits to start digital transactions, especially ZISWAF. Therefore, this study is assisted with modifying the addition of the theory of planned behavior (TPB) construct. Furthermore, this study aims to update the development of technology acceptance in society and also wants to analyze further how the role of the individual in forming habits to be able to adapt to the use of technology.

\section{Literature review}

The financial services industry is currently experiencing a significant evolution of innovation in line with the rapid development of digital technology. This innovation gave rise to the term Financial Technology (FinTech). FinTech points to technology users to provide financial solutions (Arner, Barberis, and Buckley 2015). Specifically, FinTech is defined as applying digital technology to financial intermediation problems (Aaron,

Economica: Jurnal Ekonomi Islam - Volume 11, Nomor 2 (2020) 
Rivadeneyra, and Sohal 2017). In a broader sense, FinTech is defined as an industry consisting of companies that use technology to make the financial system and delivery of financial services more efficient (World Bank, 2016). According to the Financial Stability Board (FSB), a FinTech is a technologybased financial innovation that can produce business models, applications, processes, or new products with related material effects on financial markets, institutions, and financial service providers (FSB 2017). According to The National Digital Research Center (NDRC), FinTech is innovation in financial services (innovation in the financial sector).

Based on these definitions, it can be understood that, in principle, FinTech is a fusion between technology and financial services. The use of smartphones as a mobile banking, e-wallet, e-money, and investment services can be used as an example of a combination of technology and the financial system to provide financial services that are more accessible to the broader community (Awrey 2013; Haan, Osterloo, and Schoenmaker 2009; FSB 2017). In other words, FinTech aims to provide convenience to the public in accessing financial products, facilitate transactions and also improve financial literacy.

The development of FinTech then penetrated the form of charity or alms collection. FinTech is adopted in a transaction model in charitable payments such as payment of zakat, infaq, Shadaqah, and waqf (ZISWAF). The original conventional ZISWAF was paid in cash and then evolved with non-cash payments (cashless). Many financial companies then provide charity payment facilities. Both companies that are engaged in financial services, such as banks, e-money providers, e-wallet providers and even charitable institutions. The company competes to create applications that can be accessed via smartphones to make it easier for people to give alms.

According to Junadi \& Sfenrianto (2015), the proposed model in this study will examine consumers' Intention to use e-payment system in Indonesia. It is based on a unified theory of acceptance and use of technology (UTAUT) with culture and perceived security into the model. The results 
show that all variables, namely effort expectancy, culture, perceived security, performance expectancy, and social influence, affect the Intention to use an electronic payment system.

The research conducted by Djamaludin (2020) aims to analyze the Intention to buy cinema tickets among IPB students with the theory of planned behavior (TPB) approach. The results show that attitudes towards behavior, subjective norms, and perceived behavioral control significantly affect Intention to buy electronic cinema tickets. The perceived behavioral control variable mainly influences movie ticket purchase intentions, followed by subjective norms and attitudes towards behavior.

Based on research conducted by Junadi \& Sfenrianto (2015), with the UTAUT approach, one of the founders of the UTAUT theory is TPB, and research conducted by Djamaludin (2020) shows that TPB can explain one's Intention to take action. The main factors shaping intentions are personal experience (attitude), individual external factors (subjective norms), and perceived behavioral control. Therefore, TPB is considered to describe the factors that influence individuals in forming the Intention to take action, in this case paying ZISWAF in a cashless manner.

The same thing was also conveyed by Liu \& Tai (2016). With the technology acceptance model (TAM) approach, he wanted to analyze the impact of various variables extracted from mobility, convenience, compatibility, mobile payment knowledge, ease to use, usefulness, risk, trust, and safe to use on Intention to use mobile payment in Vietnam. The results indicate that the strong predictors of the Intention to use mobile payment are perceived ease of use and perceived usefulness. The convenience of mobility, compatibility, and mobile payment knowledge impacts ease of use and benefit. Among them, compatibility has the most significant impact on ease to use and usefulness in those surveyed. Especially, it proved that trust of safe to use has no significant impact on usefulness, but instead has a direct effect on Intention to use mobile payment services.

Economica: Jurnal Ekonomi Islam - Volume 11, Nomor 2 (2020) 
Research conducted by Seetharaman et al. (2017) about factors influencing behavioral Intention to use the mobile wallet in Singapore. Use TAM approach was expanded to include innovativeness, critical mass, transaction security, trust, flexibility, cost of transaction, consumer privacy and anonymity, transaction speed, and availability of alternatives to behavior intention to use. The results confirmed that nominal transaction cost strongly influences perceived usefulness, ease of use, and transaction security, thus strengthening three influencing variables. The study highlighted that perceived usefulness and transaction security have a powerful influence over the behavioral Intention. In contrast, innovativeness, critical mass, and lack of availability of alternatives have a strong influence over the behavioral Intention, and finally flexibility has a moderate influence over the behavioral Intention. Surprisingly trust and perceived ease of use had no direct influence on behavioral Intention. While perceived ease of use, transaction cost, and transaction speed had struck a very strong influence on perceived usefulness.

The latest research by Latha \& Vatchala (2019), explored the factors influencing the mobile wallet usage intention. The results demonstrated that performance expectations, effort expectations, and trust significantly positively affect payment intention. The study results have significant theoretical and practical consequences, particularly to understand major user drivers for mobile wallet adoption.

Based on previous research, the relevant construct in explaining the phenomenon of the ease of using online payment in ZISWAF is the combined construct of TPB to see the pattern of behavior and TAM to explore the use of technology. Several previous studies provide results that the construct of TPB can describe charity paying behavior such as the influence of attitudes, subjective norms, and perceived behavioral control that have been shown to have a positive and significant influence on zakat paying compliance behavior (T. P. Simamora and Djamaludin 2020; Asmalia, Awaliah Kasri, and Ahsan 2018; Othman et al. 2017; Al Jaffri Saad and Haniffa 2014; Junadi and 
Sfenrianto 2015). In addition, other variables that are extensions of TPB such as knowledge, and trust also positively and significantly influence the behavior of paying zakat (Sapingi, Ahmad, and Mohammad 2011; Mukhlis and Beik 2013; Asmalia, Awaliah Kasri, and Ahsan 2018; Othman et al. 2017).

TPB is an extension of the theory of reasoned action (TRA). In the TRA construct, it is explained that one's Intention towards behavior is formed by two main factors, namely attitude toward the behavior and subjective norms. In contrast, in TPB one additional factor is added: perceived behavioral control (Ajzen 1991).

The main factor that forms the construct of TPB model is the individual's Intention to perform a behavior. Intention is an individual's ability to capture motivational factors so that they can influence a behavior. These motivational factors indicate how strong a person's desire to try, how much effort is planned to implement the effort (Ajzen 1991). In this theory behavioral intention consists of attitudes, subjective norms, and perceived behavioral control.

Figure 1. Construct Theory of Planned Behavior

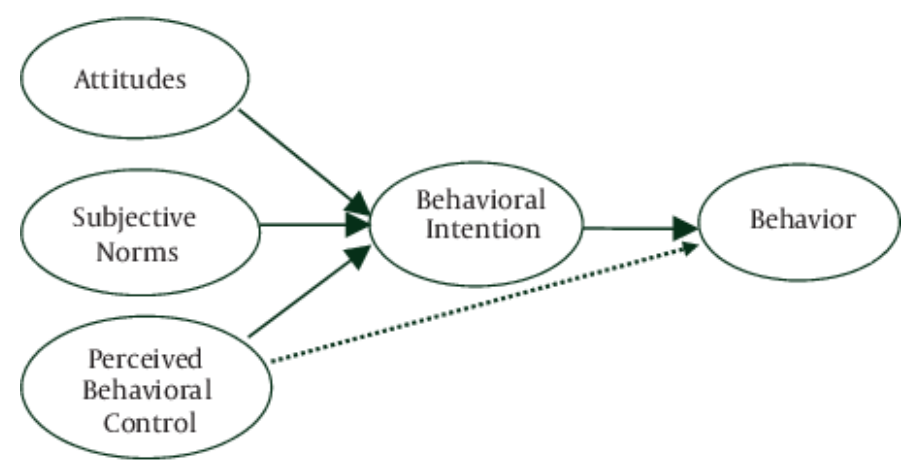

Source: (Ajzen 1991)

Economica: Jurnal Ekonomi Islam - Volume 11, Nomor 2 (2020) 
The TAM model was introduced by Fred Davis (1989). TAM is specifically designed to model user acceptance of systems or information technology, an adaptation of reasoned action. In 1989, Davis used TAM to explain computer usage behavior. The purpose of (Davis 1989) using TAM model is to describe the general determinants of computer acceptance that lead to user behavior in various end-user systems technologies. The basic TAM model tests two specific beliefs: perceived usefulness (PU) and perceived ease of use (PEoU). Perceived usefulness is defined as the subjective possibility of potential users that specific systems (e.g. e-payment platform systems) will increase their actions. Ease of use perception (perceived ease of use) refers to the extent to which prospective users expect the target system to be easy (Davis 1989).

This research integrates the TPB modeling initiated by Ajzen and TAM initiated by Davis. The combined TPB and TAM model was used in Taylor and Todd's research in 1995. Taylor and Todd examined differences in the use of information technology systems for experienced users with users who are not experienced in using the technology (Taylor and Todd 1995). The combined TAM and TPB model used in Taylor and Todd's research is often called the Augmented TAM model.

Figure 2. Construct Theory of Acceptance Model

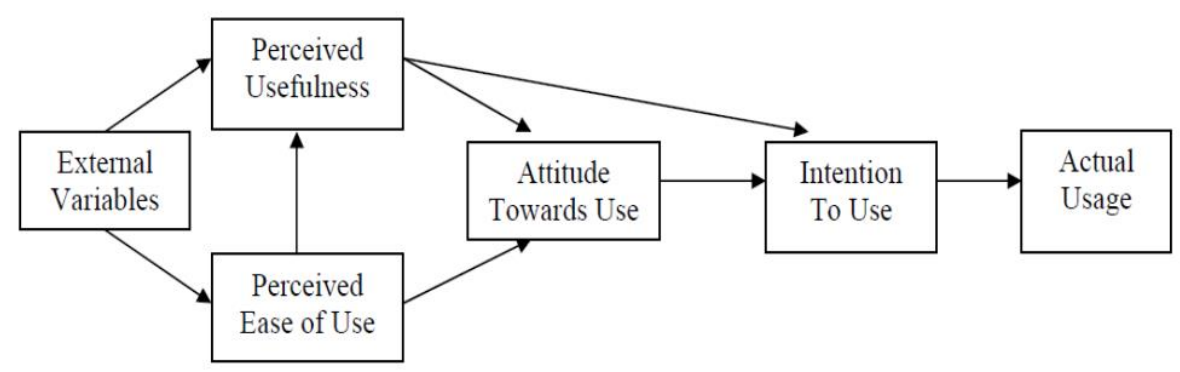

Source: (Davis 1989) 
In TAM, the attitude variable is influenced by two other main variables: perceived usefulness and ease of use. However, TAM does not include the influence of social factors and control factors on behavior, whereas in subsequent studies, it is known that both of these factors have been shown to have a significant influence on the behavior of the use of information technology. These factors are also determinants of behavior in TPB. In TPB, social factors or social influences are called subjective norms, proven to influence Intention. The control factor in TPB is perceived behavioral control (perceived behavior control) which is modeled to influence either Intention (Intention) or directly to behavior (behavior).

The modification model in this study allows the concept of technology acceptance to be accepted as a construct that influences behavior and forms an individual's Intention in paying ZISWAF. The concept of TAM is needed because the research objectives are millennial and technology literate individuals. In comparison, the TPB construct provides further information beyond technological factors, namely social factors and behavioral control, in influencing an individual's Intention to pay ZISWAF.

Figure 3. Modification of TPB and TAM Construct (Conceptual Framework)

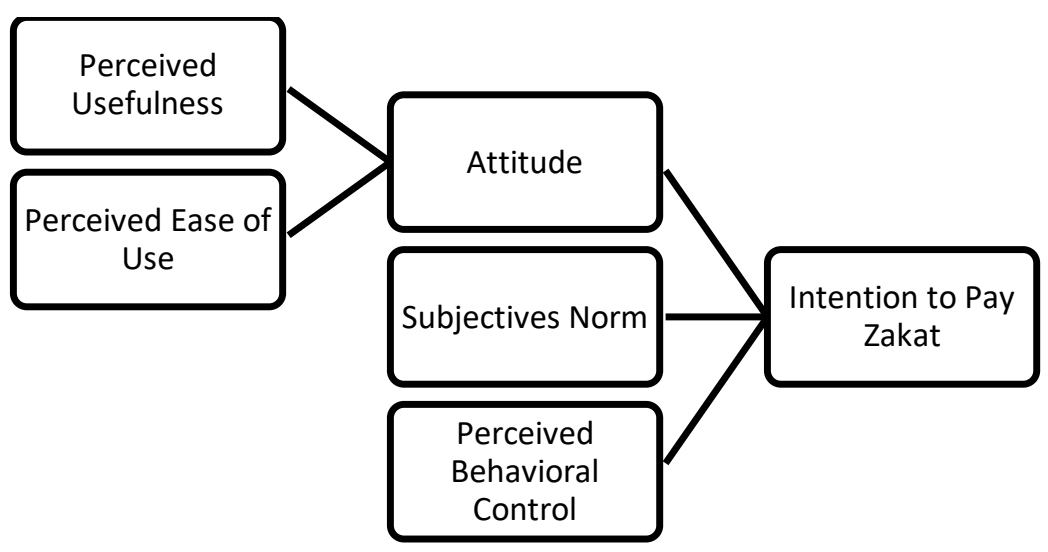

Source: Data Processed (2021)

Economica: Jurnal Ekonomi Islam - Volume 11, Nomor 2 (2020)

https://journal.walisongo.ac.id/index.php/economica 
Fuad Hasyim, Muhammad Al-Farido Awwal, and Nur Hidayah Al Amin

Table 1. Variable Indicator

\begin{tabular}{|c|c|c|}
\hline Variable & Indicator & Reff \\
\hline $\begin{array}{l}\text { Perceived Usefulness } \\
\text { (PU) }\end{array}$ & $\begin{array}{l}\text { Work More Quickly } \\
\text { Improve Job Performance } \\
\text { Increase Productivity } \\
\text { Effectiveness } \\
\text { Make Job Easier } \\
\text { Useful }\end{array}$ & (Davis 1989) \\
\hline $\begin{array}{l}\text { Perceived Ease of Use } \\
\text { (PEoU) }\end{array}$ & $\begin{array}{l}\text { Easy to Learn } \\
\text { Controllable } \\
\text { Clear \& Understandable } \\
\text { Flexible } \\
\text { Easy to Become Skillful } \\
\text { Easy to Use }\end{array}$ & (Davis 1989) \\
\hline Attitude (ATT) & $\begin{array}{l}\text { Convenience } \\
\text { Fun to Use } \\
\text { Enjoyable } \\
\text { Not Boring }\end{array}$ & $\begin{array}{l}\text { (Hill, Fishbein, } \\
\text { and Ajzen 1977) }\end{array}$ \\
\hline Subjective Norm (SN) & $\begin{array}{l}\text { Family Influence } \\
\text { Friend Influence } \\
\text { Importance Figure Influence }\end{array}$ & (Ajzen 1991) \\
\hline $\begin{array}{l}\text { Perceived Behavioral } \\
\text { Control (PBC) }\end{array}$ & $\begin{array}{l}\text { Control Beliefs } \\
\text { Power of Control Beliefs } \\
\text { Ability to Realize }\end{array}$ & (Ajzen 1991) \\
\hline Intention (INT) & $\begin{array}{l}\text { Interested in Finding Information } \\
\text { Want to Know the Product } \\
\text { Interested to Try } \\
\text { Consider to Pay ZISWAF } \\
\text { Decide to Pay ZISWAF }\end{array}$ & $\begin{array}{l}\text { (Ajzen 1991), } \\
\text { (Schiffman and } \\
\text { Kanuk 2007) }\end{array}$ \\
\hline
\end{tabular}

Source: Data Processed (2021)

\section{Methods}

The population in this study are all muzakki who use online payment models. Therefore, the sample of this research is muzakki, who uses an online payment model, especially with QR Code scanning on e-wallets, e-money, ATM or other electronic online payments.

Data retrieval model using primary data by questionnaire method. The questionnaire was used with a Likert scale score of 1-5. The distribution of the questionnaire was carried out with an online platform via Google form. The sampling method used was purposive sampling. The sample taken is the 
known Y-Generation as Millennial Generation, born between 1977-1998. YGeneration in 2020 is between 22 and 43 years old (Wilson 2010). The millennial generation was chosen to be the research target because this generation is a productive asset with great potential to participate in building economic resilience, one of which is through ZISWAF. Moreover, the millennial generation is familiar with the development of contemporary technology.

Data analysis in this study uses the Structural Equation Modeling (SEM) approach. Structural Equation Modeling (SEM) is an analytical method that combines three approaches of simultaneous analysis: checking the validity and reliability of instruments (factor analysis), testing the relationships between models (path analysis), and finding the most suitable model for regression estimation (structural analysis).

SEM uses various models to describe the relationship between variables (be they observed variables and/ or latent variables, independent or dependent), with the basic aim of providing quantitative testing of theoretical models hypothesized by researchers. In SEM analysis, there are two model analyzes. First, the measurement model is the initial model used to see how much the indicator is able to represent latent variables. The second is a structural model that shows the dependency relationship between latent variables.

To find out whether an indicator can be used as an indicator of latent variables, it is necessary to test the measurement model. The form of analysis to test the measurement model consists of validity, reliability, and goodness of fit tests. A validity test is a test conducted to test or measure the accuracy of indicators in representing latent variables. Meanwhile, the reliability test is a statistical test conducted to determine the consistency of the measurement model by looking at the construct reliability value (CR) and the variance extracted value (AVE).

Economica: Jurnal Ekonomi Islam - Volume 11, Nomor 2 (2020) 


\section{Result and discussion}

\section{Demographic respondent}

This study uses an online questionnaire with the Google Form platform. During the observation period, 96 respondents were obtained. Then tabulation and answers were checked, so all respondents were declared valid and met the criteria. The descriptive statistics on the demographics of respondents are presented as follows:

Based on the data on table 2, information is obtained that the majority of respondents taken are women. Furthermore, the data shows that women The transaction intensity will then influence the Intention to make online zakat payments.

Then in the age group, the majority of respondents are in the second (2630 ) and third age groups (31-35) in the millennial generation at the age of 2635 years with $72.9 \%$ of respondents. This shows that the millennial generation in this age range has a high enough intensity in operating the gadget. It has an impact on more online transactions and has an establishment in economic aspects. Having a high enough intensity in online transactions can be seen in

Table 2. Respondent Demographics

\begin{tabular}{llll}
\hline Gender & Percentages & Occupation & Percentages \\
\hline Male & $34,4 \%$ & Student & $36,5 \%$ \\
Female & $62,6 \%$ & PNS/ TNI/ Polri & $11,5 \%$ \\
& & Swasta/Private & $24,0 \%$ \\
& & Entrepreneur & $20,8 \%$ \\
\hline Age & Other & $7,3 \%$ \\
\hline $21-25$ & Percentages & Education & Percentages \\
$26-30$ & $4,4 \%$ & Elementary & $4,2 \%$ \\
$31-35$ & $32,6 \%$ & Junior High & $9,4 \%$ \\
$35-43$ & $17,7 \%$ & Senior High & $26,0 \%$ \\
\hline
\end{tabular}

Source: Data Processed (2021) 
the educational level of the majority of university students, which is $60.4 \%$ of respondents. In this educational range, respondents feel very close to gadgets in their daily lives, both for communication, browsing, and even online transactions. In this education group, they are already very proficient in operating the gadget. Reliability or establishment in the economic aspects can be seen at the level of work, that respondents who have worked both as civil servants/military/police, private and entrepreneurs by $56.3 \%$. This also shows that this age is within the productive age range and close to gadgets, so that it is very instrumental in strengthening the Intention to pay zakat. While age group 1 is in an economic condition that is not yet well established, while age group 4 is in a position that is less enthusiastic in using the latest technology.

\section{SEM calculation result}

The structural model is a model that describes the relationship between constructs (latent variables). The relationship between constructs is based on certain theories or assumptions. Based on the modified TAM and TPB theory in this study. The factors that influence Intention are perceived usefulness (PU), perceived ease of use (PEoU), attitude (ATT), subjective norm (SN), perceived behavioral control (PBC) and Intention to Pay Zakat (INT). The calculation results show at figure 4. 
Fuad Hasyim, Muhammad Al-Farido Awwal, and Nur Hidayah Al Amin

Figure 4. Convergent Validity
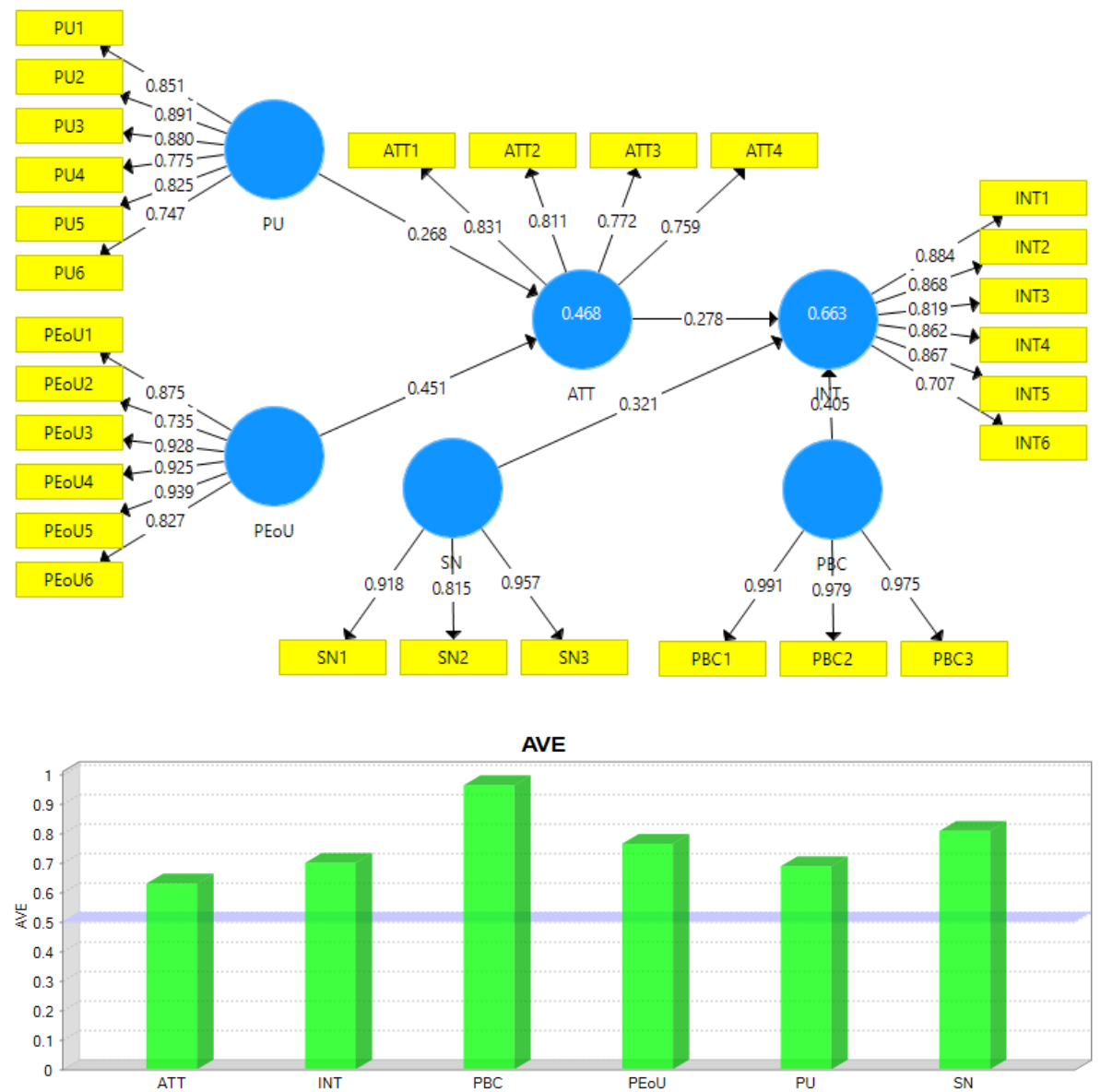

Evaluation of the model is done by measuring the convergent validity value. Convergent validity values can be seen in two ways, by looking at outer loading and the average variance extracted (AVE) value. The outer loading measurement results above show that each latent variable has a value of more than 0.5 and the value of AVE, which has a value above 0.5 , so it can be concluded that the model has convergent validity (Afthanorhan 2013). 
Table 3. Discriminant Validity

\begin{tabular}{lllllll}
\hline & ATT & INT & PBC & PEOU & PU & SN \\
\hline ATT & 0.794 & & & & & \\
INT & 0,637 & 0.837 & & & & \\
PBC & 0.403 & 0.664 & 0.981 & & & \\
PEoU & 0.664 & 0.772 & 0.653 & 0.875 & & \\
PU & 0.627 & 0.702 & 0.558 & 0.796 & 0.830 & \\
SN & 0.609 & 0.676 & 0.459 & 0.650 & 0.674 & 0.899 \\
\hline
\end{tabular}

The next test is the evaluation of the model by measuring discriminant validity. Discriminant validity can be detected by looking at the value of the internal correlation of latent variables with the correlation between latent variables. The rule of thumb that can be used is if the internal correlation value is greater than the external value, then the model meets the assumption of discriminant validity. The validity measurement results using Fornell_Lacker Criterion are obtained as shown at table 3.:

Based on the results of the above output, the results show that the intrinsic correlation value is higher than the correlation between variables, so it can be concluded that the model has no discriminant validity problem. The evaluation of the next model is by measuring the reliability of the model. Model reliability can be seen with two test results, namely Cronbach's Alpha and Composite Reliability. The rule of thumb that can be used is if the reliability value is greater than 0.7 , then the assumption of the model evaluation in reliability testing is accepted (Rina 2019; Latan and Noonan 2017; Afthanorhan 2013). The validity measurement results using CA and CR are obtained as as shown at table 4. :

Table 4. Reliability Testing

\begin{tabular}{lcc}
\hline & Cronbach's Alpha & Composite Reliability \\
\hline ATT & 0.822 & 0.872 \\
INT & 0.913 & 0.933 \\
PBC & 0.981 & 0.987 \\
PEoU & 0.938 & 0.951 \\
PU & 0.909 & 0.930 \\
SN & 0.878 & 0.926 \\
\hline
\end{tabular}

Economica: Jurnal Ekonomi Islam - Volume 11, Nomor 2 (2020) 
Based on the table 4, it is obtained information that the Cronbach Alpha and Composite Reliability values are above 0.7 . Thus it can be concluded that the measurement model of all variables has good reliability. Therefore, after testing the quality of the measurement model is completed, and the measurement model is declared valid and reliable, then the next step is testing the hypothesis.

The mediating effect shows the relationship between variables exogenous and endogenous through the connecting variable (mediating). For example, if the variance account for (VAF) value is above $80 \%$, showing the role of attitude variable (ATT) in the TAM construct is a complete mediation. On the other hand, the attitude implementation variable (ATT) is categorized as partial mediation if the VAF value ranges from $20 \%$ to $80 \%$. Still, if the VAF value is less than $20 \%$, it can be concluded that there is almost no mediating effect.

Table 5. Total Effect and Path Coeficient

\begin{tabular}{rccccc}
\hline & Orig. & Std. & T Stat & \multicolumn{2}{c}{ P Value } \\
& Total & $\begin{array}{l}\text { Path } \\
\text { Effect }\end{array}$ & Coef. \\
\hline ATT > INT & 0.278 & 0.091 & 3.054 & & $0.002^{*}$ ) \\
PBC > INT & 0.405 & 0.092 & 4.406 & & $0.000^{*}$ ) \\
PEoU > ATT & 0.451 & 0.117 & 3.858 & & $0.000^{*}$ ) \\
PEoU > INT & 0.125 & 0.051 & 2.440 & $0.015^{*}$ ) & \\
PU > ATT & 0.268 & 0.128 & 2.092 & & $0.037^{*}$ ) \\
PU > INT & 0.075 & 0.045 & 1.872 & $\left.0.095^{* *}\right)$ & \\
SN > INT & 0.321 & 0.113 & 2.829 & & $0.005^{*}$ ) \\
\hline
\end{tabular}

*) Significance at $\alpha$ level 0.05

**) Significane at $\alpha$ level 0.1 
Table 6. Indirect, Direct Effect and VAF

\begin{tabular}{lll}
\hline \multicolumn{1}{c}{ Indirect Effect } & Calculation & Total \\
\hline PEoU > ATT; ATT > INT & $0.451^{*} 0.278$ & 0.125 \\
PU > ATT; ATT > INT & $0.268^{*} 0.278$ & 0.074 \\
Total Indirect Effect & & 0.199 \\
\hline \multicolumn{1}{c}{ Direct Effect } & & \\
\hline PEoU > INT & 0.125 & 0.125 \\
PU > INT & 0.075 & 0.075 \\
Total Direct Effect & & 0.200 \\
\hline Total Indirect and Direct Effect & $\mathbf{0 . 1 9 9 + 0 . 2 0 0}$ & 0.399 \\
\hline VAF & $\mathbf{( 0 , 1 9 9 / 0 . 3 9 9 ) * 1 0 0 \%}$ & $\mathbf{4 9 , 8 7 \%}$ \\
\hline
\end{tabular}

Based on the table 6 calculation, results obtained a VAF value of $49.87 \%$. Therefore, in this case, the TAM constructs the effect of PEoU and PU on INT is partial mediating/ quasy mediating with ATT as a mediating variable.

\section{Discussion}

The results show that all constructs of exogenous variables affect endogenous variables at the $\alpha$ level of 5\%, except the perceived usefulness (PU) variable in influencing attitude (ATT) at the $\alpha$ level of $10 \%$. Thus, the construct of this study is also partial mediating/quasi mediating in modeling the TAM theory. Therefore, this study supports the research construct with the TPB modeling initiated by Ajzen, $(1985,1991)$ and TAM initiated by Davis (1989).

In the TAM construct, it is stated that perceived usefulness (PU) affects the Intention (INT) both directly and indirectly (partial mediating) at the $\alpha$ level of $10 \%$. This number means that perceived usefulness (PU) is able to influence individual intentions, whether mediated by attitude (ATT) or not. Based on this study, it was found that the individual felt that the breakthrough in using financial technology in ZISWAF payments was beneficial in supporting their activities. The indicators used in this study show that muzaki feels that payment procedures are easier, faster, more effective, and efficient.

Economica: Jurnal Ekonomi Islam - Volume 11, Nomor 2 (2020) https://journal.walisongo.ac.id/index.php/economica 
From this convenience, the potential for ZISWAF payments can be maximized. Moreover, online payment users start to squirm in a few years and are predicted to be increasingly massive for several years to come. Therefore, at least the projected acceptance of ZISWAF based on this study will reach around $88.3 \%$ based on the assumption of the total coefficient of direct influence on Intention (ceteris paribus condition).

Another TAM construct is perceived ease of use (PEoU). PEoU also has direct and indirect effects on INT. PEoU is an aspect of convenience that is seen from the perspective of the application used. Financial technology that is used in the digital era today is very diverse by offering ease of use. Transactions can be done through digital platforms with e-wallet systems such as QR Scanning through the Gopay, OVO, Dana, and other applications. In addition, transactions can also be done with e-money, ATMs, to merchants that provide online payments such as retail minimarkets. The use of technology is very close to the activities of modern humans today, especially among millennials. Gadgets become inseparable and become the primary needs. Using an online payment application is also very easy, with a simple menu, clear orders, and just a click away. The ease of this transaction offered encourages individuals to apply it in ZISWAF payments. As a result, millennials are very skilled at playing gadgets so that online ZISWAF payments are more manageable. The application convenience raises the potential for the ZISWAF payment campaign to be vigorously promoted by both the government and the authorities in charge. Therefore, the application is likely to increase the ZISWAF revenue target. This supports the research conducted Davis (1989), Rouibah ( 2009) and Wong et al. (2013), Wiharjo \& Hendratmi (2020), Baskoro \& Karmanto, 2020), Purwanto et al., (2021) that PU and PEoU have a significant effect on Intention.

Attitude (ATT) is a factor in a studied person providing a positive or negative response to the assessment of something given. In this study, respondents had positive experiences in using online platforms in ZISWAF 
payments. The TAM construct has previously been explained that online payment innovations provide convenience in terms of benefits and tools that are easy to use, thus stimulating individuals to tend to use them continuously. In terms of TPB, it can also be analyzed that the encouragement of ease in forming positive experiences increases the addiction to digital platforms in ZISWAF payments. This is in line with the process of people's interest in using halal products because the response of positive experiences of individuals on the use of halal products has the potential to create a habit of consuming them (Mohamed Omar et al. 2012; Aziz et al. 2015; Abdul Latiff et al. 2016; S.-L. Wong, Hsu, and Chen 2018; Hasyim 2018; Hasyim and Nurohman 2021; Purwanto, Sulthon, and Wafirah 2021; Wiharjo and Hendratmi 2020).

Subjective norm (SN) is a person's perception of the thoughts of others who will support or not support him in doing something. Thus, subjective norm refers to the social pressures faced by individuals to do or not do something. On the other hand, if attitude (ATT) emphasizes the empirical experience of oneself, then the Subjective Norm is the influence of others who then adapt themselves. For example, some respondents stated that the ZISWAF payment activity they do is the influence of friends or family who first practice it. Then they apply in their payment transaction activities, and they feel significantly helped by it. Therefore, external influences also significantly impact motivating individuals to do something (Shih and Fang 2004; Shah Alam and Mohamed Sayuti 2011; Moons and De Pelsmacker 2012; Hasyim 2019; Yusfiarto, Setiawan, and Nugraha 2020; Hasyim and Nurohman 2021). Therefore, if the promotion is carried out intensively by ZISWAF authorities, the possibility of realizing the national ZISWAF achievement target will be achieved.

Perceived behavioral control (PBC) is the perception of ease or difficulty in performing a behavior. This study shows that some obstacles in making online payment transactions are the signal stability of telecommunications providers and hang servers. However, these obstacles rarely occur, so it does 
not so inhibit online payment activities. Based on the results of the output data, it is obtained that perceived behavioral control (PBS) significantly influences Intention (INT). This is obtained by finding that the constraints experienced by respondents can be obtained solutions to overcome them so that these obstacles are not a significant problem. These results are consistent with (Bulutoding, Parmitasari, and Suhartono 2019; Pratama and Sukmana 2020; Aziz et al. 2015; Abdul Latiff et al. 2016; S.-L. Wong, Hsu, and Chen 2018; Yusfiarto, Setiawan, and Nugraha 2020; Asmalia, Awaliah Kasri, and Ahsan 2018) findings which state that the obstacles do not make it difficult to make a halal product purchase.

\section{Conclusion}

This study proves that the combination of TAM and TPB can predict an increase in ZISWAF payment potential in Indonesia. Individuals who are respondents feel the convenience offered is a trigger for them to pay for ZISWAF online. Effectiveness and efficiency are the main reasons they use online payment applications. In addition, the massive promotion of collaboration between online payment providers via QR Code, e-wallet, emoney, banking, and online transaction provider institutions has increased ZISWAF's revenue target nationally.

The recommendation for the government is to activate digital literacy campaigns for the wider community. In addition, support for telecommunications companies to expand the signal area covered by the internet so that people can enjoy and make good use of digital technology. So that with the synergy between the government, zakat institutions connected to digital platforms will accelerate ZISWAF collection optimally. However, the limitation of this study lies in the user object. In this case, the sample used is still limited to millennials. If it is applied in every age category, the constraints offered by convenience will be a challenge because not every age category is well-using gadgets or digital understanding information. 


\section{References}

Aaron, Meyer, Francisco Rivadeneyra, and Samantha Sohal. 2017. "Fintech: Is This Time Different? A Framework for Assessing Risks and Opportunities for Central Banks." Bank of Canada Staff Discussion Paper 10: 1-32.

Abdul Latiff, Zul Ariff Bin, Golnaz Rezai, Zainalabidin Mohamed, and Mohamad Amizi Ayob. 2016. "Food Labels' Impact Assessment on Consumer Purchasing Behavior in Malaysia." Journal of Food Products Marketing 22 (2): 137-46. https://doi.org/10.1080/10454446.2013.856053.

Afthanorhan, Wan Mohamad Asyraf Bin Wan. 2013. "A Comparison Of Partial Least Square Structural Equation Modeling (PLS-SEM) and Covariance Based Structural Equation Modeling (CB-SEM) for Confirmatory Factor Analysis." Certified International Journal of Engineering Science and Innovative Technology (IJESIT). Vol. 2.

Ajzen, Icek. 1985. "From Intentions to Actions: A Theory of Planned Behavior." In Action Control, 11-39. Berlin, Heidelberg: Springer Berlin Heidelberg. https://doi.org/10.1007/978-3-642-69746-3_2.

_- . 1991. "The Theory of Planned Behavior." Organizational Behavior and Human Decision Processes 50 (2): 179-211. https://doi.org/10.1016/0749-5978(91)90020-T.

Arner, Douglas W., Janos Nathan Barberis, and Ross P. Buckley. 2015. "The Evolution of Fintech: A New Post-Crisis Paradigm?" SSRN Electronic Journal. https://doi.org/10.2139/ssrn.2676553.

Asmalia, Sarah, Rahmatina Awaliah Kasri, and Abdillah Ahsan. 2018. "Exploring the Potential of Zakah for Supporting Realization of Sustainable Development Goals (SDGs) in Indonesia." International Journal of Zakat 3 (4): 51-69. https://doi.org/10.37706/ijaz.v3i4.106.

Awrey, Dan. 2013. "Toward a Supply-Side Theory of Financial Innovation." Journal of Comparative Economics 41 (2): 401-19. https://doi.org/10.1016/j.jce.2013.03.011.

Aziz, Noreen Noor Abd, Nurul Aien Abd.Aziz, Nurul Ashykin Abd Aziz, Zurina Omar, and Wan Haslin Aziah Wan Hassan. 2015. "A Review on the Emergence and Growth of Halal Studies." Procedia Economics and Finance 31 (January): 325-32. https://doi.org/10.1016/S22125671(15)01204-6.

Economica: Jurnal Ekonomi Islam - Volume 11, Nomor 2 (2020) 
Baskoro, Bimmo Dwi, and Gina Destrianti Karmanto. 2020. "Intensi Masyarakat Dalam Menyalurkan Zakat, Infaq, Dan Shadaqah (Zis) Melalui Penggunaan Platform Crowdfunding." Point 2 (2): 95-109. https://doi.org/10.46918/point.v2i2.748.

Baznas. 2019. "BAZNAS Sampaikan 6 Capaian Sukses Pada Rakornas Zakat 2019." BAZNAS. 2019.

Bulutoding, Lince, Rika Dwi Ayu Parmitasari, and Suhartono. 2019. "Perilaku Kepatuhan Para Wajib Zakat Di Provinsi Sulawesi Selatan." Laa Maisyir 6 (2): 191-210. https://doi.org/10.24252/lamaisyir.v6i2.11800.

Davis, Fred D. 1989. "Perceived Usefulness, Perceived Ease of Use, and User Acceptance of Information Technology." MIS Quarterly 13 (3): 319. https://doi.org/10.2307/249008.

Franedya, Roy. 2019. "Terungkap! Transaksi GoPay Di 2018 Tembus Rp 87 T.” CNBC Indonesia. 2019. https://www.cnbcindonesia.com/tech/20190211103125-3754742/terungkap-transaksi-gopay-di-2018-tembus-rp-87-t.

FSB. 2017. "FinTech Credit: Market Structure, Business Models and Financial Stability Implications." BIS Media and Public Relation.

Gia-Shie Liu, and Pham Tan Tai. 2016. "A Study of Factors Affecting the Intention to Use Mobile Payment Services in Vietnam." Economics World 4 (6): 249-73. https://doi.org/10.17265/2328-7144/2016.06.001.

Haan, Jakob De, Sander Osterloo, and Dirk Schoenmaker. 2009. European Financial Market and Institutions. New York: Cambridge University Press.

Hasyim, Fuad. 2018. "The Determinant of Takaful Acceptance: Theory of Reasoned Action Approach." Journal of Finance and Islamic Banking 1(1). https://doi.org/10.22515/jfib.v1i1.1246.

———. 2019. "Peer To Peer Lending As Alternative Online Microfinance Platform: Threat and Challenge To Islamic Microfinance." Indonesian Journal of Islamic Literature and Muslim Society 4 (2): 2528-1194. https://doi.org/10.22515/islimus.v4i2.1491.

Hasyim, Fuad, and Yulfan Arif Nurohman. 2021. "Adopsi Teori Perilaku Berencana Dalam Menganalisis Niat Melakukan Wakaf Tunai." Among Makarti 14 (1). https://doi.org/10.52353/ama.v14i1.201. 
Hill, Richard J., Martin Fishbein, and Icek Ajzen. 1977. "Belief, Attitude, Intention and Behavior: An Introduction to Theory and Research." Contemporary Sociology 6 (2): 244. https://doi.org/10.2307/2065853.

Jaffri Saad, Ram Al, and Roszaini Haniffa. 2014. "Determinants of Zakah (Islamic Tax) Compliance Behavior." Journal of Islamic Accounting and Business Research 5 (2): 182-93. https://doi.org/10.1108/JIABR-102012-0068.

Junadi, and Sfenrianto. 2015. "A Model of Factors Influencing Consumer's Intention To Use E-Payment System in Indonesia." Procedia Computer Science $59 \quad$ (Iccsci): $214-20$. https://doi.org/10.1016/j.procs.2015.07.557.

Karmanto, Gina Destrianti, A Jajang W Mahri, and Aas Nurasyiah. 2021. "Society Intention in Distribution of Zakat, Infaq and Shadaqah (ZIS) through the Use of Crowdfunding Platform." Falah: Jurnal Ekonomi Syariah 6 (1): 30-44. https://doi.org/10.22219/jes.v6i1.15133.

Lai, PC. 2017. "The Literature Review Of Technology Adoption Models And Theories For The Novelty Technology." Journal of Information Systems and Technology Management 14 (1): 21-38. https://doi.org/10.4301/S1807-17752017000100002.

Latan, Hengky, and Richard Noonan. 2017. Partial Least Squares Path Modeling. Edited by Hengky Latan and Richard Noonan. Partial Least Squares Path Modeling: Basic Concepts, Methodological Issues and Applications. Cham: Springer International Publishing. https://doi.org/10.1007/978-3-319-64069-3.

Latha, R, and C Vatchala. 2019. "Exploring the Factors Influencing the Mobile Wallet Usage Intention" 7 (2): 77-81.

Mohamed Omar, Khairi, Nik Kamariah Nik Mat, Gaboul Ahmed Imhemed, and Fatihya Mahdi Ahamed Ali. 2012. "The Direct Effects of Halal Product Actual Purchase Antecedents among the International Muslim Consumers." American Journal of Economics 2 (4): 87-92. https://doi.org/10.5923/j.economics.20120001.20.

Moons, Ingrid, and Patrick De Pelsmacker. 2012. "Emotions as Determinants of Electric Car Usage Intention." Journal of Marketing Management 28 (34): 195-237. https://doi.org/10.1080/0267257X.2012.659007. 
Mukhlis, Ahmad, and Irfan Syauqi Beik. 2013. "Analisis Faktor-Faktor Yang Memengaruhi Tingkat Kepatuhan Membayar Zakat: Studi Kasus Kabupaten Bogor." Al-Muzara'ah 1 (1): 83-106. https://doi.org/10.29244/jam.1.1.83-106.

Othman, Yusuf Haji-, Ibadurrahman Alwi, Mohd Sholeh Sheh Yusuff, and Mohd Shahid Azim Mohd Saufi. 2017. "The Influence of Attitude, Subjective Norm, and Islamic Religiosity on Compliance Behavior of Income Zakat Among Educators." International Journal of Academic Research in Business and Social Sciences 7 (11). https://doi.org/10.6007/IJARBSS/v7i11/3549.

Pratama, Mutia Fatiha, and Raditya Sukmana. 2020. "Analisis Faktor-Faktor Tpb Dan Religiosity Terhadap Willingness Dalam Berwakaf Pengurus Muhammadiyah Di Kota Surabaya." Jurnal Ekonomi Syariah Teori Dan Terapan 7 (4): 633. https://doi.org/10.20473/vol7iss20204pp633-645.

Purwanto, Purwanto, Muhammad Sulthon, and Milna Wafirah. 2021. "Behavior Intention to Use Online Zakat: Application of Technology Acceptance Model with Development." Ziswaf: Jurnal Zakat Dan Wakaf 8 (1): 44. https://doi.org/10.21043/ziswaf.v8i1.10457.

Republika. 2019. "Baznas Harap Zakat Digital Di Indonesia Jadi Inspirasi Dunia." Republika. 2019.

Rina, Lelahester. 2019. "Student Leadership In School: Internalization Of Entrepreneurial Competence And Character." Jurnal Manajemen Dan Kewirausahaan 21 (1): 1-8. https://doi.org/10.9744/jmk.21.1.1-8.

Rouibah, Kamel, Ramayah Thurasamy, and Oh Sook May. 2009. "User Acceptance of Internet Banking In Malaysia." International Journal of EAdoption 1 (1): 1-19. https://doi.org/10.4018/jea.2009010101.

Sapingi, Raedah, Noormala Ahmad, and Marziana Mohammad. 2011. "A Study On Zakah Or Employment Income: Factors That Influence Academics Intention to Pay Zakah." In. Pahang, Malaysia.

Schiffman, Leon, and Lazar Leslie Kanuk. 2007. Perilaku Konsumen Edisi Kedua. PT. Indeks Gramedia.

Seetharaman, A, Karipur Nanda Kumar, S Palaniapan, and Golo Weber. 2017. "Factors Influencing Behavioural Intention to Use the Mobile Wallet in Singapore." Journal of Applied Economics and Business Research 7 (2): 116-36. 
Shah Alam, Syed, and Nazura Mohamed Sayuti. 2011. "Applying the Theory of Planned Behavior (TPB) in Halal Food Purchasing." International Journal of Commerce and Management 21 (1): 8-20. https://doi.org/10.1108/10569211111111676.

Shih, Ya-Yueh, and Kwoting Fang. 2004. "The Use of a Decomposed Theory of Planned Behavior to Study Internet Banking in Taiwan." Edited by Fang Kwoting. Internet Research 14 (3): 213-23. https://doi.org/10.1108/10662240410542643.

Simamora, Novita Sari. 2019. "Aplikasi Pembayaran Online Dongkrak Penghimpunan Zakat." Solopos. 2019.

Simamora, Tria Putri, and Moh Djemdjem Djamaludin. 2020. "Analysis of Intention to Buy Cinema E-Tickets Among IPB Students with Theory of Planned Behavior (TPB) Approach." Journal of Consumer Sciences 5 (1): 58-72. https://doi.org/10.29244/jcs.5.1.58-72.

Taylor, Shirley, and Peter A Todd. 1995. "Understanding Information Technology Usage: A Test of Competing Models." Information Systems Research 6: 144-76.

Utami, Pertiwi, Tulus Suryanto, M Nasor, and Ruslan Abdul Ghofur. 2020. “The Effect Digitalization Zakat Payment Against Potential of Zakat Acceptance in National Amil Zakat Agency." IQTISHADIA 13 (2): 216. https://doi.org/10.21043/iqtishadia.v13i2.7809.

Wiharjo, Bahana, and Achsania Hendratmi. 2020. "Persepsi Kegunaan, Kemudahan Penggunaan, Keamanan Dan Privasi Serta Kepercayaan Dalam Penggunaan Zakat Online: Dengan Pendekatan Tam." Jurnal Ekonomi Syariah Teori Dan Terapan 6 (2): 331. https://doi.org/10.20473/vol6iss20192pp331-343.

Wilson, Alan. 2010. "Book Review: Grown up Digital: How the Net Generation Is Changing Your World." International Journal of Market Research 52 (1): 139-40. https://doi.org/10.2501/S1470785310201119.

Wong, Kung Teck, Rosma bt Osman, Pauline Swee Choo Goh, and Mohd Khairezan Rahmat. 2013. “Understanding Student Teachers' Behavioural Intention to Use Technology: Technology Acceptance Model (TAM) Validation and Testing." International Journal of Instruction 6 (1): 89-104.

Wong, Song-Lin, Cheng-Chin Hsu, and Han-Shen Chen. 2018. “To Buy or Not to Buy? Consumer Attitudes and Purchase Intentions for Suboptimal Food."

Economica: Jurnal Ekonomi Islam - Volume 11, Nomor 2 (2020) 
Fuad Hasyim, Muhammad Al-Farido Awwal, and Nur Hidayah Al Amin

International Journal of Environmental Research and Public Health 15 (7): 1431. https://doi.org/10.3390/ijerph15071431.

Yusfiarto, Rizaldi, Ananda Setiawan, and Septy Setia Nugraha. 2020. "Literacy and Intention to Pay Zakat." International Journal of Zakat 5 (1): 15-27. https://doi.org/10.37706/ijaz.v5i1.221. 